\title{
Türkiye'de Ticaret Sürecinde Yer Alan Tarafların Ticaretin Kolaylaştırılması Üzerine Karşılıklı Beklentileri
}

\author{
Mine Yılmazera, b, Berk Nuhoğluc
}

Özet

Anahtar Kelimeler

Uluslararası ticaret, ülkelerin kalkınmasında önemli bir paya sahiptir. Bu sebeple Türkiye'de dış ticaret sürecinde bulunan tarafların birbirlerinden beklentilerini belirlemek, ticaretin hızlandırılmasına ve kolaylaştırılmasına ilişkin görüşlerini, eksikleri ve çözüm önerilerini ortaya çıkarmak büyük önem taşımaktadır. Bu bağlamda çalışmada, Dünya Ticaret Örgütü (DTÖ) tarafından hazırlanan Ticareti Kolaylaştırma Anlaşması (TFA) ve bu anlaşmanın uygulanmasında referans niteliği taşıyan performans göstergelerinde Türkiye'nin durumu incelenmiş ve TFA'nın uygulanmasıyla elde edilebilecek kazançlar ele alınmıştır. Türkiye'nin bu göstergelerdeki durumuna istinaden, ticaret sürecinde karşılaşılan sorunları belirlemek amacıyla görüşme soruları hazırlanmış ve ticaret sürecinde yer alan firmalar ve gümrük yetkililerine yöneltilmiştir. Görüşmeler Nitel Araştırma Yönteminin bir veri toplama tekniği olan Derinlemesine Görüşme ile yapılmıştır. Elde edilen veriler NVIVO programı ile analiz edilmiştir. Analiz sonucunda, gümrük işlem ve prosedürlerinde, ticaret sürecindeki belgelerin elektronik ortama uyarlanmasında ve uluslararası koordinasyon konularında iyileştirmeler yapılması gerektiği belirlenmiştir. Sonuç bölümünde ise elde edilen bulguların ortaya çıkardığı sorunların çözümlenmesine ve beklentilerin karşılanmasına yönelik öneriler getirilmeye çalışılmıştır.

\section{Trade Facilitation and Mutual Expectations of Parties Involved in Turkey's International Trade}

\begin{abstract}
International trade plays an important role in the development of countries. Determining the expectations of the parties in the process of international trade, problems they encounter, views on possible solutions and their opinion on trade facilitation is important. In this study, Turkey's situation in the performance indicators of TFA was analyzed and the possible benefits of the implication of TFA are discussed. Interview questions to determine the problems encountered in the process of trade has been prepared using these indicators and asked to companies and customs authorities involved in the process. Interviews were conducted with In-Depth Interview which is a technique of Qualitative Research Method. The data obtained were analyzed with NVIVO. As a result, it was determined that improvements should be made in customs procedures, electronic documents, and international coordination. In the conclusion part, suggestions were made to solve the problems arising from the findings and to meet the expectations.
\end{abstract}

Keywords

Trade Facilitation

Paperless Trade

Customs Procedures

Import and Export

About Article

Received: 01.03.2021

Accepted: 21.06.2021

Doi: 10.18026/cbayarsos.872621

\footnotetext{
${ }^{1}$ Çalışma Yüksek Lisans Tezinden Üretilmiştir.

a İletişim Yazarı: mine.yilmazer@gmail.com

b Prof. Dr., Manisa Celal Bayar Üniversitesi, https://orcid.org/ 0000-0001-8674-792X

c Doktora Öğrencisi, Manisa Celal Bayar Üniversitesi, https://orcid.org/0000-0003-1438-8440
} 


\section{Giriş}

Son yıllarda küreselleşmenin de etkisiyle, birçok ülkenin dış ticarette başarı göstererek küresel ekonomik gücünü artırdığı gözlenmektedir. Bu sebeple, uluslararası ticaret kavramı büyük bir önem kazanmıştır ve gerek uluslararası kuruluşlar gerekse ülkeler ticaret hacimlerinin artmasına, ticaretin kolaylaştırılması ve hızlandırılmasına, şeffaflığa yönelik kapsamlı çalışmalar yapmaktadır. Şüphesiz ki 1948 yılında faaliyete geçen Gümrük Tarifeleri ve Ticaret Genel Anlaşması (GATT) anlaşmasının 1995 yılında DTÖ halini alması ile birlikte atılan adımlar, dünya ticareti için büyük önem taşımaktadır. DTÖ tarafından hazırlanıp 2017 yılında yürürlüğe giren TFA ise bu çalışmaların en büyük meyvesi olarak karşımıza çıkmaktadır.

TFA ile alınan önlemler sayesinde ortaya çıkabilecek verimlilik artışının, Türkiye'nin dış ticarette rekabetinin yükselmesine ve ülkenin ekonomik yönden gelişimine katkı sağlaması öngörülmektedir. Bu çalışmanın ana konusunu, Türkiye'de TFA çerçevesinde alınan önlemlerin bu önlemleri uygulayanların dış ticaret performansına etkileri oluşturmaktadır. Bu bağlamda öncelikle TFA ve performans göstergeleri detaylı bir şekilde incelenmiş; sonrasında TFA'nın uygulanması sürecinde referans niteliği taşıyan performans göstergelerinde Türkiye'nin durumu ortaya çıkarılmaya çalışılmıştır. Çalışmada ayrıca anlaşma yükümlülüklerini yerine getiren taraflardan sürecin hızlandırılması ve kolaylaştırılmasına ilişkin görüşler ve çözüm önerileri alabilmek için pilot bir çalışma yapılmıştır. Bu kapsamda, İzmir ve Manisa bölgesinde faaliyette bulunan firmalar ve gümrük idaresi yetkilileri ile derinlemesine görüşmeler yapılmıştır. Araştırmadan elde edilen bulguların, Türkiye'de dış ticaretin kolaylaştırılması ve hızlandırılması yönünde yapılan çalışmalara katkı sağlaması beklenmektedir. Doğrudan sahada ve aktif şekilde faaliyette bulunanların birbirlerinden ve karar alıcılardan beklentilerini de ortaya çıkarmaya çalışan bu araştırmanın politika uygulanmasında yol gösterici olması arzu edilmektedir.

Çalışmanın birinci bölümünde ticaret sürecinde verimlilik için kilit nokta olan tedarik zinciri ve yönetimine, bu sürecin maliyet unsurlarına değinilmiştir. Ayrıca ticaret sürecinde yer alan taraflar, süreç içerisindeki prosedürler, işlemler ve belgeler detaylı bir şekilde incelenmiştir. Çalışmada ticaretin kolaylaştırılması kavramı, çeşitli ülkelerin bu sürece yaklaşımları ve stratejileri incelenmiştir. TFA'nın 11 performans göstergesi detaylı bir şekilde incelenmiş ve her performans başlığında, Türkiye'nin diğer ülkeler arasındaki yeri kıyaslanmış ve ortalamanın altında kaldığı performans göstergeleri belirlenmiştir. Uluslararası kurumların hazırladığı, Lojistik Performans Endeksi (LPI) gibi endeksler ve Türkiye'nin bu endekslerdeki puanları, endekslerdeki lider ülkeler ile kıyaslanmış ve olası sorunlara 1şık tutulması amaçlanmıştır. Takip eden başlıklarda, elde edilen bu veriler değerlendirilmiş, TFA performans göstergeleri ve uluslararası endeksler detaylı bir şekilde incelenmiş, Türkiye'nin dünya ortalaması altında kaldığı göstergeler ve endeksler baz alınarak ticaret sürecinde yer alan taraflara yöneltilecek görüşme soruları hazırlanmıştır. Hazırlanan görüşme soruları, firmalara ve gümrük yetkililerine derinlemesine görüşme tekniği kullanılarak yöneltilmiş, elde edilen cevaplar analiz edilmiş ve ticaret sürecinin hızlanması ve kolaylaştırılması ile ilgili önemli bilgiler elde edilmiştir.

\section{Dış Ticarette Tedarik Zinciri ve İthalat İhracat Süreci Yönetimi}

Tedarik zinciri, bir ürünün veya hizmetin hammadde teminini sağlayan, bu ürünleri üretime dahil ederek yarı mamul ve mamullere dönüşmesine yol açan, devamında elde edilen bu yarı mamul ve mamulleri son tüketici veya müşterilere dağıtım kanalları aracılığıyla ulaştırmak 
görevini üstlenen bir ağ veya şebeke olarak tanımlanabilir (Eymen, 2007). Tedarik zinciri, diş ticaret için en önemli kazanç faktörlerinden biridir ve Malzeme Planlama, Üretim ve Entegrasyon, Depolama ve Tamamlama, Dağıtım, Onarım ve Geri Dönüş olmak üzere toplam beş basamaktan oluşmaktadır. Bu basamaklardaki etkinlik ve verimlilik, bir firmanın uluslararası ticaret hacmini ve performansını doğrudan etkilemektedir.

\section{Tedarik Zinciri Yönetimi ve Verimlilik}

Ulusal ve uluslararası piyasalarda güçlü bir rekabet yaratabilmek için tedarik zinciri yönetiminin başarıyla yürütülebilmesi son derece önemlidir. En temel anlamıyla Tedarik Zinciri Yönetimi, hammaddenin temininden, üretime, üretim sonrası dağıtım ile ürünlerin son tüketiciye kadar ulaşması sürecinde yer alan aktörler arasında ürün, para ve bilgi yönetimi olarak tanımlanmaktadır (Özdemir, 2004: 89). Tedarik zinciri ağ yapısı, tedarikçiler, ürünlerin muhafaza edildiği depolar, distribütörler, üreticiler ve perakendeciler gibi bir tedarik zincirine dahil olarak aktörler arasındaki ilişkileri belirlemektedir. Tedarik zinciri yönetiminin asli amaçları, Özdemir (2004) tarafından yapılan çalışmada aşağıdaki gibi açıklanmıştır.

a. Müşterinin memnuniyetini artırmak,

b. Çevrim zamanını azaltmak,

c. Stok maliyetlerini minimize etmek,

d. Üretiminde meydana gelen hataları minimize etmek,

e. Tüm faaliyetler sonucu doğan genel maliyetleri azaltmaktır.

$\mathrm{Bu}$ amaçların başarıya ulaşabilmesindeki en önemli etken, tedarik zinciri içerisindeki haberleşme ve bilgi paylaşımının arttırılması olarak ifade edilmiştir. Tedarik zinciri içerisindeki etkin bilgi paylaşımı ve haberleşmenin zincirin rekabetçiliği açısından önemli bir rol oynayabileceği beklenmektedir. Tedarik Zinciri Yönetimi, bir firmanın verimliliği ve rekabet edebilirliği açısından büyük önem taşımaktadır. Tedarik zincirinde, atık ve israfın önüne geçildiğinde veya mümkün olan en alt seviyelere düşürüldüğünde, üretim yapan şirketin karlılığının artması, üretim maliyetlerinin düşmesi ve dolayısıyla küresel rekabetçiliğinin yükselmesi mümkün olacaktır. Tedarik zincirinde ortaya çıkabilecek israfın nedenleri arasında fazla üretim, bekleme, taşıma, gereksiz işlem, gereksiz hareket, tamir ve fireler, stok yönetimi yer almaktadır. Bu değişkenler, tedarik zinciri maliyetlerini açıkça ortaya koymaktadır.

Ticaret maliyetlerinin düşürülmesi ve ticareti kolaylaştırma açısından tedarik zinciri yönetiminin etkin yapılması firmalara ve ülkelere ticaret sürecinde büyük faydalar sağlama potansiyeline sahiptir.

\section{Uluslararası Tedarik Zinciri}

İhracat ve ithalat süreci, yapısı gereği birçok aktörün katılımı, prosedürler ve uygulamalar ile sürdürülmektedir. Bu süreçte, ticaret maliyetlerini düşürmek ve rekabetçi avantaj elde edebilmek için, ithalat ve ihracat yönteminin en etkin ve doğru şekilde yapılması gerekmektedir. Uluslararası tedarik zinciri diş ticarete konu olan ürünlerin mevzuata uygun şekilde ulusal sınırlar dışına gönderilmesi, nakliye ve ödeme işlemlerinin güvenli ve sağlıklı bir şekilde yapılması yönündeki işlemler bütünüdür. Uluslararası ticarette ülkeye ve ürüne göre farklı belgeler hazırlanmakta ve çeşitli prosedürler uygulanmaktadır. DTÖ ve Uluslararası Ticaret Odası (ICC) gibi kurumlar, bu uygulamaların standartlaştırılması ve 
kolaylaştırılması için çaba harcamaktadır. Bu amaçla ICC, standart teslim ve ödeme şekillerini açıklayan ve ticari sözleşmelerde kullanılabilen kavramlar geliştirmiştir (OAİB, 2020).

Uluslararası tedarik zincirindeki tarafları ve prosedürleri açıklamak üzere, Birleşmiş Milletler (UN) ve Ticaret Kolaylaştırma ve Elektronik İşletmeciliği Merkezi (CEFACT) tarafından BuyShip-Pay (BSP) yani “Satın Al-Gönder-Öde” modeli geliştirilmiştir.

Şekil 1'de UN/CEFACT'ın uluslararası ticaret zinciri modeli detaylı bir şekilde gösterilmiştir.

Şekil 1. UN/CEFACT - Satın Al - Gönder - Öde Modeli
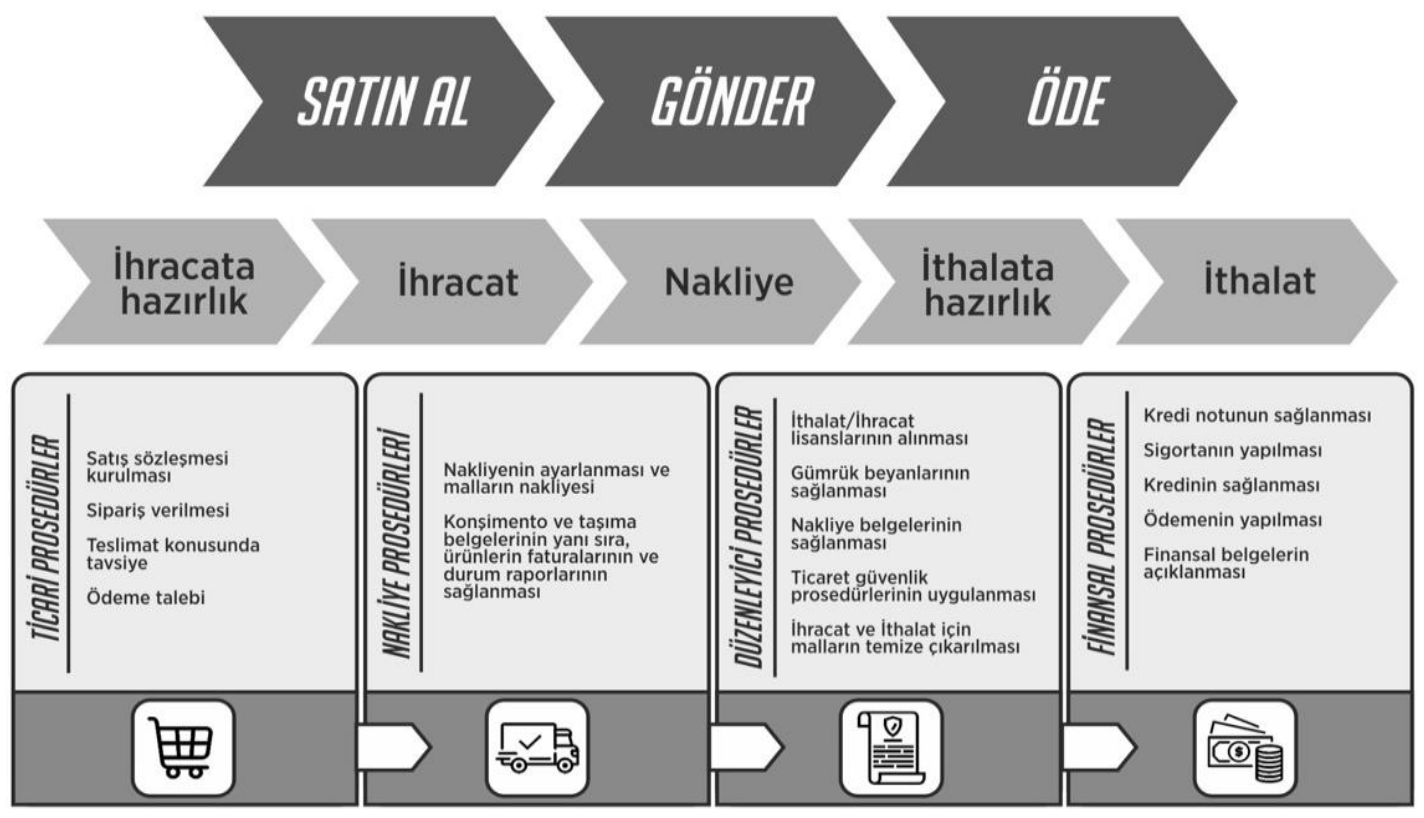

Kaynak: UN/CEFACT Buy-Ship-Pay Model, 2012

BSP tedarik zinciri satın alma, gönderme ve ödeme başlıkları altında ticari, nakliye, düzenleyici ve finansal prosedürler şeklinde dört ana başlık altında incelenen iş sürecini kapsamaktadır. Bu model uluslararası ticaret zincirinde yer alan tarafları, gerçekleştirilen prosedürleri ve ticaretin kolaylaştırılması için gereken uygulamaları göstermesi açısından da önemlidir (UN/CEFACT, 2003). Uluslararası ticaretin kolaylaştırılması anlayışı, UN/CEFACT tarafından bu çerçevede şekillendirilmiştir. Uluslararası ticaretin kolaylaştırılması kavramı, bir ürün ihracatçıdan ithalatçıya ulaştırılırken gerçekleştirilen tüm işlemlerin basitleştirilmesi, ödemenin yapılması ve prosedürlerin ülkeler arasında standart hale getirilerek birbiri arasında uyumlaştırılması şeklinde açıklanmıştır.

\section{Dış Ticaretin Kolaylaştırılması ve Türkiye}

Günümüzde uluslararası ticaret kavramının teorik altyapısı Adam Smith'in Ulusların Zenginliği kitabına dayanmaktadır. Smith, kitabında ülkelerin iş bölümü halinde çalışmalarından söz etmiş ve her ülkenin en düşük maliyetle ürettiği üründe uzmanlaşması gerektiğini belirtmiştir. Teoride, iş bölümünün her ülkenin aynı anda zenginleşmesini sağlaması beklenmekteydi. Bununla birlikte uygulamada gelişmekte olan ülkeler aleyhine bazı adaletsizlikler ortaya çıkmış ve bu ülkelerin dış ticarette söz sahibi olması sağlanamamıştır. Uluslararası adaletsizlikleri giderme konusundaki en önemli uygulamalardan biri olan ve Birleşmiş Milletler Kalkınma Programı tarafından oluşturulan Sürdürülebilir Kalkınma Hedefleri ekonomik eşitsizlikleri gidermek, yoksulluk, iklim 
değişikliği, sürdürülebilir tüketim, yenilikçilik gibi başlıkları içeren 17 amaç üzerine kurulmuştur. 17. hedef "Uluslararası ticaretin geliştirilmesi ve gelişmekte olan ülkelerin ihracatını artırmalarına destek verilmesi, adil ve açık, herkesin yararına olan, evrensel kurallara dayalı ve hakkaniyetli bir ticaret sistemini oluşturmanın unsurları" şeklinde tanımlanmıştır (UNDP, 2020). Ticaretin kolaylaştırılması çabaları uluslararası standartların belirlenmesi, yenilikçiliğin desteklenmesi, bürokrasinin önlenmesi, işlemlerin dürüst, adil ve şeffaf bir şekilde yürütülmesi amaçlarını içermektedir. Uluslararası ticaretin kolaylaştırılması konusunda atılacak her adımın gelişmekte olan ülkelerin uluslararası pazarlara açılmasını, pazardaki yerini güçlendirmesini ve döviz gelirini artırmasını sağlaması beklenmektedir. Bu doğrultuda, ülkeler arasındaki eşitsizlikle mücadele edilebilecektir.

Ticareti kolaylaştırma kavramı farklı şekillerde tanımlanmaktadır. Bunlar arasında en net tanım DTÖ'ye aittir. DTÖ’nün tanımına göre ticaretin kolaylaştırılması kavramı, uluslararası ticareti planlanan bir malın, bir noktadan diğerine ulaştırılması için gerekli olan tüm verilerin toplanması, bu verilerin sunulması ve iletilmesi, elde edilen bu verilerin işlemden geçirilmesi sürecindeki işlem ve prosedürlerin basitleştirilmesi, standart hale getirilmesi ve formalitelerin azaltılması ve uzun vadede tamamen ortadan kaldırılması anlamına gelmektedir (WTO, 2020).

Uluslararası tedarik zincirinde gerçekleştirilen işlemlerin daha hızlı ve düşük maliyetle tamamlanabilmesi uluslararası pazarlarda hareketliliği artırmaktadır. Pazardaki hareketlilik sayesinde, gelişmiş ülkeler yanında gelişmekte olan ülkeler de bu pazarlarda yer edinebilmekte ve diş ticaret hacimlerini yükseltebilmektedir. Her ülkenin maliyet avantajı ile dahil olduğu uluslararası ticaret ortamı, bir yandan dünya kaynaklarının daha etkin kullanımına ve diğer taraftan tüketici refahının artmasına katkı yapmaktadır. Bu nedenle ticaretin kolaylaştırılmasına yönelik çabalar özellikle son yıllarda artış göstermiştir. Bu çabaların, DTÖ'nün kuruluşundan sonra 1990'l1 yıllarda hız kazandı̆̆ı ve örgüte üye ülkelerin gerçekleştirdiği toplantılarda alınan kararlar doğrultusunda şekillendiği görülmektedir. DTÖ çatısı altında yapılan anlaşmalar dahilinde uluslararası ticarette, tüm tarafların kabul edip uygulayacağ1 ve işlemleri hızlandıracak ortak bir dil belirlemek amacıyla standartlar oluşturulmuş, hukuki kurallar koyularak olası anlaşmazlıklar için tahkim kurulları oluşturulmuş, bilgiye erişim şeffaf hale getirilmiş, ülkelerin performansını ölçmek ve yetersizlikleri ortaya çıkarabilmek için uluslararası endeksler hazırlanmış ve sistematik bir şekilde güncellenmesi sağlanmıştır. DTÖ tarafından oluşturulan Ticaretin Kolaylaştırılması Anlaşması (TFA), bu konudaki en güncel uygulamalardan biridir. TFA, 7 Aralık 2013 tarihinde Endonezya'nın Bali kentinde imzalanmış, 27 Kasım 2014 tarihinde Marakes, Anlaşması'nda görüşülmüş ve 22 Şubat 2017 tarihinde yürürlüğe girmiştir.

DTÖ'nün faaliyetlerine ek olarak, Ekonomik Kalkınma ve İşbirliği Örgütü (OECD) ticareti kolaylaştırma konusunda önemli çalışmalar yapmaktadır. OECD ticareti kolaylaştırma alanında birçok çalışma yapmış ve ülkelerin ticaret maliyetlerini azaltmalarına, ticaret akışlarını artırmalarına ve uluslararası ticaretten daha fazla fayda elde etmelerine yardımcı olmak için, eylem alanlarını belirlemiş ve reformların potansiyel etkilerini değerlendiren bir dizi ticari kolaylaştırma göstergesi ortaya koymuştur OECD, aynı zamanda ülkelerin ticaretin kolaylaştırılması ile ilgili performanslarını değerlendirmek üzere bazı kriterler belirlemiştir. $\mathrm{Bu}$ kriterleri ölçmek üzere kullanılan değişkenlerle Ticaretin Kolaylaştırılması Endeksi hesaplanmış ve ülkeler performanslarına göre sıralanmıştır (OECD, 2020).

Küresel ekonomiye entegre olmaya çalışan ülkeler, ticaretin kolaylaştırılması politikalarının hayata geçirilmesine önem vermektedir. Uluslararası standartlarda ve kaliteli hizmetin hızlı 
bir şekilde yerine getirilmesi, ülkelerin rekabetçiliğini artırmaktadır. Benzer şekilde uygulanan ticareti kolaylaştırma politikaları, Türkiye'nin uluslararası piyasalardaki konumunu güçlendirmektedir. Bu nedenle Türkiye'de konuya özel önem verilmiş, 2016 yılında "Ticaretin Kolaylaştırılması Kurulu" oluşturulmuştur. Kurul, gerçekleştirilen çalışmaları “Ticaretin Kolaylaştırılması Türkiye Stratejisi ve Eylem Planı 2018-2022" başlıklı rapor ile yayınlamıştır.

Türkiye'de söz konusu eylem planının uygulanmasıyla birlikte 2022 yılı sonuna kadar gerçekleşmesi beklenen faaliyetler aşağıda özetlenmiştir (Ticaret Bakanlığı, 2020).

a. Ticari belgelerin güncel kurallar çerçevesinde doğru, hızlı ve anlaşılır bir şekilde yayımlanması,

b. Yeni kanunlar ve mevzuatların oluşturulması ya da mevcut mevzuatların değiştirilmesi durumunda, taraflardan görüş talep edilmesi ve yapılan değişimlerin zamanında ve şeffaf bir şekilde bildirilmesi,

c. Sınır idareleri tarafından talep edilen belgeler, formaliteler, harçlar ve ücretler revize edilerek şeffaflı̆̆ın sağlanması,

d. Gümrük idareleri altyapılarının iyileştirilmesi,

e. Malların gümrük idarelerinde kırmızı hatta düşme ihtimalinin azaltılması ve işlemlerin hızlandırılması,

f. Transit geçişlerin kolaylaştırılması,

g. Sınır işlemlerinin basitleştirilmesi,

h. Ticari tarafların rekabetçi üstünlük elde edebilmesi için gereken iyileştirme ve geliştirmelerin yapılması hedeflenmektedir.

$\mathrm{Bu}$ kapsamda, hedeflere ulaşabilmek için beş temel eylem belirlenmiştir (Ticaret Bakanlığı, 2020).
a. Gümrük ve Ticaret Prosedürlerinde Şeffaflığın Sağlanması,
b. Gümrük ve Ticaret Prosedürlerinin Kolaylaştırılması,
c. Ticari Maliyetlerin Azaltılması,
d. Gümrük ve Ticaret Prosedürlerinden Sorumlu Kurumlar Arasında ve Üçüncü Ülke İdareleri ile İşbirliğinin Geliştirilmesi,
e. Ticaretin Kolaylaştırılmasında Kapasitenin Geliştirilmesi.

\section{Ticaretin Kolaylaştırılması Göstergeleri ve Türkiye}

Ticareti kolaylaştırma kapsamında OECD'nin belirlemiş olduğu bir çalışma grubu, yapılacak olan faaliyetler, uygulamalar ve formaliteleri daha belirgin hale getirmek ve daha anlaşılır ve ölçülebilir olmasını sağlamak amacıyla yapılan çalışmalar ve araştırmalar sonucunda 11 maddelik ticareti kolaylaştırma ilkesi belirlenmiştir. Bu ilkeler dikkate alınarak, her ülkenin performansı hesaplanmaktadır. Performansa göre ülkelere 0 ile 2 arasında değişen puanlar verilmektedir. Tablo 1'de Türkiye'nin tam puan olan 2 üzerinden aldığı değerler, taraf ülkelerin ortalama puanı ile karşılaştırılarak gösterilmiştir. 
Tablo 1. Ticaretin Kolaylaştırılması Göstergeleri ve Türkiye

\begin{tabular}{lcc}
\hline OECD Göstergeleri & $\begin{array}{c}\text { Taraf Ülkelerin } \\
\text { Ortalama Puanı }\end{array}$ & Türkiye Puanı \\
\hline Bilgiye Erişim & 1,672 & 1.476 \\
Ticaret Erbabı ile İstişare & 1.706 & 1.625 \\
Mevzuata İlişkin Bilgi Taleplerinin & 1.681 & 1.118 \\
Karşılanması & 1.602 & 1.50 \\
Başvuru Prosedürleri & 1.822 & 1.692 \\
Ücretler ve Masraflar & 1.743 & 1.125 \\
Belgeler & 1.745 & 1.70 \\
Otomasyon & 1.625 & 1.570 \\
İşlem Prosedürleri & 1.341 & 1.70 \\
Sınır Teşkilatı İşsel İşs birliği & 1.54 & 818 \\
Sınır Teşkilatı Dışsal İş birliği & 1.908 & 1.889 \\
Yönetişim ve Tarafsızlık & & \\
\hline
\end{tabular}

Kaynak: OECD, 2020

Bu bağlamda, Türkiye' nin göstergeler nezdinde birçok maddede dünya ortalamasının altında kaldığı ve dünya ortalamasının üzerine çıkabilmek için önemli adımlar atılması gerektiği görülmektedir. Küreselleşen dünyada, bilişim sistemlerinin, haberleşmenin ve teknolojinin katlanarak arttığı zamanda, ticaret sürecinde yapılan işlemlerin, ödemelerin otonom ve çevrimiçi hale getirilmesinin, ticaret sürecinin tek bir çevrimiçi portal üzerinden gerçekleştirilmesinin önemi açıkça ortaya çıkmaktadır.

\section{Uluslararası Endekslerde Türkiye}

OECD'nin ticaretin kolaylaştırılması göstergelerine dayanarak gerçekleştirdiği performans sıralamasına benzer şekilde ülkelerin uluslararası ölçekte rekabet gücünü ölçen birçok endeks hesaplanmaktadır. Dünya Bankası, Dünya Ekonomik Forumu (WEF) gibi uluslararası kuruluşlar tarafından hesaplanan bu endekslerin sonuçları düzenli bir şekilde güncellenen raporlarla yayınlanmaktadır. Tablo 2'de, Ticareti Kolaylaştırma ile doğrudan bağlantılı olan bazı endeksler ele alınmıştır. Söz konusu endekslerde ilk 10 ülke ile Türkiye'nin sıralaması ve puanı karşılaştırmalı olarak gösterilmiştir. Lojistik Performans Endeksinde ülkeler, ticaret sürecindeki lojistik performansları, gümrükler, altyapı ve şeffaflık gibi maddeler üzerinden değerlendirilirken, İş Yapabilirlik Endeksi ise, şeffaflık, hukuki yap1 ve formaliteleri değerlendirmektedir. Küresel Rekabetçilik Endeksi, kurumların etkinliğini ve altyapılarını, ekonomik istikrarı, iş gücünü ve mevcut teknolojilerin kullanımı gibi önemli maddeleri ölçmekte, Küresel Ticareti Kolaylaştırma Endeksi ise gümrük idarelerinin performanslarını, ülkelerin ticaret yönetimi kalitelerini ölçmektedir. Bu endeksler, ticaretin kolaylaştırılması amacına hizmet eden alt değişkenlere sahiptir. Ticaretin kolaylaştırılmasının en temel amaçları 
verilerin sunulması ve iletilmesi, bu verilere ait işlem ve prosedürlerin basitleştirilmesi, standart hale getirilmesi ve formalitelerin azaltılmasıdır. Bu kapsamda, diğer endekslerde başarı sağlayan ülkelerin ticaretin kolaylaştırılması hedeflerine uyum sağlaması beklenmektedir.

Tablo 2. Uluslararası Endeksler ve Türkiye'nin Yeri

\begin{tabular}{|c|c|c|c|c|c|c|c|c|c|c|c|}
\hline \multicolumn{3}{|c|}{$\begin{array}{l}\text { Lojistik Performans } \\
\text { Endeksi- } 2018\end{array}$} & \multicolumn{3}{|c|}{$\begin{array}{l}\text { İş Yapabilirlik Endeksi- } \\
2020\end{array}$} & \multicolumn{3}{|c|}{$\begin{array}{l}\text { Küresel Rekabet } \\
\text { Edebilirlik Endeksi- } \\
2019\end{array}$} & \multicolumn{2}{|c|}{$\begin{array}{l}\text { Küresel Ticaretin } \\
\text { Kolaylaştırılması } \\
\text { Endeksi- } 2016\end{array}$} & \multirow[b]{2}{*}{ Puan } \\
\hline Sira & Ülke & Puan & Sira & Ülke & Puan & Sira & Ülke & Puan & Sira & Ülke & \\
\hline 1 & Almanya & 4,2 & 1 & $\begin{array}{c}\text { Yeni } \\
\text { Zelanda }\end{array}$ & 86.8 & 1 & Singapur & 84.8 & 1 & Singapur & 5.97 \\
\hline 2 & İsveç & 4,05 & 2 & Singapur & 86.2 & 2 & $\mathrm{ABD}$ & 83.7 & 2 & Hollanda & 5.70 \\
\hline 3 & Belçika & 4,04 & 3 & Hong Kong & 85.3 & 3 & Hong Kong & 83.1 & 3 & Hong Kong & 5.66 \\
\hline 4 & Avusturya & 4,03 & 4 & Danimarka & 85.3 & 4 & Hollanda & 82.4 & 4 & Lüksemburg & 5.63 \\
\hline 5 & Japonya & 4,03 & 5 & $\begin{array}{c}\text { Kore } \\
\text { Cumhuriyeti }\end{array}$ & 84.0 & 5 & İsviçre & 82.3 & 5 & İsveç & 5.61 \\
\hline 6 & Hollanda & 4,02 & 6 & $\mathrm{ABD}$ & 84.0 & 6 & Japonya & 82.3 & 6 & Finlandiya & 5.60 \\
\hline 7 & Singapur & 4 & 7 & Gürcistan & 83.7 & 7 & Almanya & 81.8 & 7 & Avusturya & 5.52 \\
\hline 8 & Danimarka & 3,99 & 8 & İngiltere & 83.5 & 8 & İsveç & 81.2 & 8 & İngiltere & 5.52 \\
\hline 9 & İngiltere & 3,99 & 9 & Norveç & 82.6 & 9 & İngiltere & 81.2 & 9 & Almanya & 5.48 \\
\hline 10 & Finlandiya & 3,97 & 10 & İsveç & 82.0 & 10 & Danimarka & 81.2 & 10 & Belçika & 5.29 \\
\hline 47 & Türkiye & 3,15 & 33 & Türkiye & 76.8 & 61 & Türkiye & 62.1 & 59 & Türkiye & 4.52 \\
\hline
\end{tabular}

Kaynak: The World Bank: Logistics Performance Index, 2018, The World Bank: Doing Business Index, 2020, World Economic Forum: Global Competitiveness Report, 2019, World Global Trade Enabling Report 2016.

Dört adet uluslararası endeksin son verileri karşılaştırıldığında, Singapur, Hong Kong, Almanya, İngiltere, Japonya, Hollanda gibi ülkelerin her endekste yüksek başarı gösterdiği görülmektedir. Bu başarı genel olarak güçlü bir altyapı hizmetlerine, düşük maliyetli ve basitleştirilmiş prosedürlere, teknolojik gelişmelere ve otomasyonun gücüne sahip olmalarına bağlıdır. Uluslararası endekslerin gösterdiği üzere, Türkiye'nin sıralamadaki yeri gelişmiş ülkelerin bir hayli aşağısındadır (Tablo 2). Ticareti Kolaylaştırma konusunda atılacak adımların ve Ticareti Kolaylaştırma göstergelerinde yapılacak iyileştirmelerin endeks puanlarında pozitif etkiler yapabileceği görülmektedir.

\section{Literatür İncelemesi}

Uluslararası literatürde, ticaretin kolaylaştırılması üzerine çeşitli çalışmalar bulunmaktadır. Literatürde yoğunlaşılan konu ise, ticaret maliyetlerinin azaltılması ve ihracatın artırılmasıdır. Duval vd. (2015)'nin çalışmalarında, 44 Asya ülkesi incelenmiş ve TFA tam olarak uygulandığı taktirde ticaret maliyetlerinde \%11 oranında düşüş yaratacağ 1 öngörülmüştür. Moise vd. (2012), 26 OECD ülkesini değerlendirip ticareti kolaylaştırma göstergelerinden Ücretler ve Harçlar, Otomasyon, Prosedürlerin Kolaylaştırılması ve Bağlayıcı Tarife Bilgisi (BTB) olmak 
üzere 4 tanesinin tam olarak uygulandığ1 taktirde ticari maliyetlerde \%13,5 düşüş beklemektedirler.

Bir diğer çalışmada Sakyi vd. (2017), 35 Afrika ülkesinin sınır idareleri ve taşımacılık etkinliklerini incelemiş, ticareti kolaylaştırmanın ekonomik büyümeye olası etkilerini araştırmışlardır. Elde edilen verilere göre, ticareti kolaylaştırmanın ekonomik büyüme üzerine pozitif etki yapacağını belirtmişlerdir.

Uluslararası literatürde odaklanılan bir diğer konu ise, gümrükleme ve limanların etkinliği olarak karşımıza çıkmaktadır. Shepherd ve Wilson (2007), çalışmalarında liman verimliliğinin ticareti kolaylaştırma ilkeleri baz alınarak arttırılması halinde, küresel ölçekte imalat sektöründe 377 milyar ABD Doları değerinde artış olacağını öngörmüşlerdir.

Hillberry ve Zhang (2015) OECD üyesi ülkelerin sınır idarelerindeki gümrükleme süreçlerini detaylı bir şekilde analiz etmiştir. OECD üyesi ülkelerin ortalama ithalat sürelerinin 1,6 günden eğer TFA'nın ilkeleri tam olarak uygulanırsa 0,9 güne indirilebileceğini, ihracat sürelerinin ise ortalama 1,9 günden 1,2 güne indirilebileceğini öngörmüştür.

Grainger (2014) ise gümrükleme maliyetlerin ticareti kolaylaştırmanın karşısında büyük bir engel teşkil ettiğini savunmuş, ticareti kolaylaştırmanın tam olarak uygulanabilmesi için gümrüklere ve gümrüklerin altyapılarına özel önem gösterilmesi gerektiğini vurgulamıştır.

Literatürde, ticareti kolaylaştırma uygulamalarını Türkiye özelinde inceleyen çalışmalar da yapılmıştır. Örneğin, Deliçay (2015), Türkiye'nin ulusal koordinasyon çalışmalarını değerlendirmiş, TFA'nın uygulanmasının önemini, ne denli uygulandığını ve anlaşmanın tam uygulanması halinde elde edilebilecek pozitif etkileri detaylı bir şekilde incelemiştir. Çalışmada ithalat ve ihracat maliyetlerinin OECD ülkelerinin maliyetlerinin bir hayli üzerinde olduğu ortaya çıkarılmış, ülke içinde koordinasyon sorunları olduğu, sınır birimlerinin birbirleri ve ülkenin diğer kurumları arasında yeterli bilgi paylaşımı yapmadığı belirtilmiştir.

Aynagöz Çakmak (2016), TFA'nın Türkiye açısından önemini incelemiştir. Bu çalışmada, TFA'nın uygulanmasında Türkiye'nin eksikliklerine dikkat çekilmiş, uluslararası endekslerde Türkiye'nin durumu değerlendirilmiştir. Elde edilen verilerde gümrüklerde talep edilen belge sayısının, AB ülkeleri içerisindeki en yüksek sayı olduğu görülmüştür. Aynagöz Çakmak, kurumların şeffaflığı ve ticaret sürecindeki bilgilendirme zinciri üzerinde durmuş, Türkiye'nin kurumlarının şeffaflık alanında daha iyi bir seviyeye getirilmesi için çalışmalar yapılması gerektiğini savunmuştur. Bununla birlikte güvenlik koşulları ve teknolojinin yakından takip edilmesi, son teknolojik gelişmelere hızlı bir şekilde uyum sağlayabilmenin önemini belirtmiştir.

Uluslararası endeksleri inceleyen bir diğer çalışma ise Bahçeci (2018), tarafından yapılmıştır. $\mathrm{Bu}$ çalışmada Türkiye'nin ticareti kolaylaştırma adına attığı adımlar değerlendirilmiştir. Bahçeci atılan altyapı adımlarına, Ticareti Kolaylaştırma Komitesi'nin kurulmasına dikkat çekmiş ancak atılan adımların sadece bir başlangıç olduğu, uluslararası endekslerde daha rekabetçi bir pozisyona çıkabilmek için, şeffaflık, gümrükleme, prosedürlerin basitleştirilmesi ve formalitelerin ortadan kaldırılması, maliyetler ve işbirliği gibi, TFA'nın en önemli maddelerinde iyileştirmeler yapılması gerektiğini ortaya koymuştur.

Bir diğer araştırma ise, Ünsal (2007) tarafından yapılmış ve Singapur, İsveç ve ABD gibi ülkelerde yürürlükte olan, TFA'nın en önemli maddelerinden biri olan "Tek Pencere" sistemi incelenmiştir. Bu çalışmada "Tek Pencere" sisteminin önemine değinilmiş, uygulanması 
halinde diş ticaret maliyetlerinin dramatik şekilde azalacağı ve ticaret hacminin artacağ 1 belirtilmiştir.

Uluslararası arenada Türkiye'yi de içine alan bir araştırma ise OECD (2015) tarafından uygulanmıştır. Bu araştırmada OECD ülkeleri analiz edilmiş, TFA'nın eksiksiz bir şekilde uygulanması halinde, Türkiye'nin de aralarında bulunduğu üst-orta gelir düzeyine sahip ülkelerde ticari maliyetlerin \%14,6 düşmesi beklendiği öngörülmüştür.

\section{Araştırmanın Yöntemi}

$\mathrm{Bu}$ çalışmada, ticaretin kolaylaştırılması politikalarının dış ticaret operasyonunu yürüten taraflara etkisi incelenmeye çalışılmıştır. Araştırmada, nitel araştırma yönteminin bir veri toplama tekniği olan “Derinlemesine Görüşme Tekniği" seçilmiştir. Veri toplamak için öncelikle ikincil veri kaynaklarından yararlanılmış ve literatür taraması yapılmıştır. Buradan elde edilen detaylı bilgilerle görüşme soruları hazırlanmıştır. Sonrasında birincil veri kaynağı olarak uzman görüşlerine başvurulmuştur. Birincil kaynaktan veri toplamak amaciyla gerçekleştirilen derinlemesine görüşmeler, diş ticaret sürecinde aktif rol alan büyük çaplı işletmelere ve dış ticaret prosedürleri açısından büyük bir etkiye sahip olan gümrük idarelerine uygulanmıştır. Yapılan görüşmelerin sonunda ticareti kolaylaştırma faaliyetleri konusunda tarafların uygulamalarını, elde ettikleri kazançlarını, yaşadıkları sorunları ve beklentilerini ortaya çıkarabilmek amaçlanmıştır.

Araştırmanın çalışma evreni, İzmir ve Manisa bölgesinde faaliyet gösteren, ithalat ve ihracat yapan işletmeler ve ithalat ve ihracat sürecinde etkin rol oynayan gümrük idaresi olarak belirlenmiştir. Araştırmanın örneklemini ise, İzmir ve Manisa bölgesinde faaliyet gösteren 10 adet ithalat ve ihracat yapan işletme ve 5 adet gümrük yetkilisi oluşturmaktadır. Araştırma, işletmelerin ve gümrük idaresinin uluslararası ticaret sürecinde yürüttükleri prosedürlerin ve işlemlerin uyumu, bu sürecin kolaylaştırması ve hızlandırılması açısından birbirlerinden beklentilerini belirlemek amacıyla, DTÖ Ticareti Kolaylaştırma Anlaşması ve bu anlaşmaya yönelik literatür taraması sonucunda hazırlanan görüşme sorularının taraflara yöneltilmesi ve görüşlerinin alınması ile sınırlandırılmıştır.

Katılımcı firmalar ve gümrük yetkililerinin seçilmesi için yargısal örnekleme yöntemi kullanılmıştır. Bu bağlamda yüksek miktarda dış ticaret işlemi ve gümrük işlemi yapan firmalar üzerinde çalışma yapılması kararlaştırılmıştır. Yargısal örnekleme metodu ile tespit edilen firmalar içerisinden kolayda örnekleme yöntemi kullanılarak İzmir ve Manisa bölgesinde faaliyet gösteren 10 firma ve 5 gümrük yetkilisi ile görüşmeler gerçekleştirilmiştir. Görüşme yapılan firmaların bilgileri Tablo 3'de gösterilmektedir.

Tablo 3. Katılımcı Firmaların Profilleri

\begin{tabular}{lll}
\hline Firma & Faaliyet Alanı & Merkezi \\
\hline A Firması & Kaynak Malzemeleri Üretimi ve İhracatı & Manisa \\
B Firması & Jant Üretimi ve İhracatı & Manisa \\
C Firması & Kuru Üzüm Üretimi ve İhracatı & Manisa \\
D Firması & Bitki Koruma ve Tarım Ürünü Üretimi ve İhracatı & İzmir \\
E Firması & Beyaz Eşya ve Elektronik & Manisa \\
F Firması & Tekstil ve Dış Ticaret & İzmir
\end{tabular}




\begin{tabular}{lll} 
G Firması & Danışmanlık, Lojistik ve Dış Ticaret & Manisa \\
H Firması & Kurutulmuş Gıda Üretim ve İhracatı & Manisa \\
I Firması & Plastik ve Petrokimya & İzmir \\
J Firması & Plastik Ambalaj & Manisa \\
\hline
\end{tabular}

Kaynak: Yazar Tarafından Düzenlenmiştir.

Katılımcı firmalardan alınan gerekli izinler doğrultusunda, görüşmelerin gerçekleştirildiğ $i$ yetkililerin katılımcı profilleri Tablo 4 de belirtilmiştir.

Tablo 4. Katılımcı Firmaların Profilleri

\begin{tabular}{ll}
\hline Çalıştığı Firma & Pozisyon / Unvanı \\
\hline A Firması & İhracat Sorumlusu \\
B Firması & İthalat Uzmanı \\
C Firması & Genel Müdür \\
D Firması & Genel Müdür + İhracat Müdürü \\
E Firması & İthalat İhracat Uzmanı \\
F Firması & Diş Ticaret Sorumlusu \\
G Firması & Diş Ticaret Operasyon Müdürü \\
H Firması & Şirket Sahibi \\
I Firması & İthalat Uzmanı \\
J Firması & Genel Müdür \\
\hline
\end{tabular}

Kaynak: Yazar Tarafından Düzenlenmiştir.

Görüşme yapılan 5 gümrük yetkilisinden alınan izinler doğrultusunda, katılımcı profilleri Tablo 5'te belirtilmiştir.

Tablo 5. Katılımcı Firmaların Profilleri

\begin{tabular}{ll}
\hline Gümrük Yetkilisi & Pozisyon/Ünvanı \\
\hline Gümrük Yetkilisi A & Gümrük ve Ticaret Baş Müfettişi \\
Gümrük Yetkilisi B & Gümrük Yetkilisi \\
Gümrük Yetkilisi C & Gümrük ve Ticaret Baş Müfettişi \\
Gümrük Yetkilisi D & Gümrük Müdürü \\
Gümrük Yetkilisi E & Gümrük Yetkilisi \\
\hline
\end{tabular}

Kaynak: Yazar Tarafından Düzenlenmiştir.

Yukarıda profilleri belirlenen katılımcılara, ticaret sürecinde birbirlerinden beklediklerini belirlemek amacıyla, Türkiye'nin Tablo.1'de verilen OECD Ticareti Kolaylaştırma Anlaşması göstergelerinden, ortalama altında kaldığı maddeler ve uluslararası endekslerde düşük performans gösterilen maddeler dikkate alınarak şirketler ve gümrüklere karşılıklı sorular 
yöneltilmiştir. Veri toplama süreci, Koronavirüs (COVID-19) sebebiyle, e-mail ve telefon görüşmeleri ile sürdürülmüş elde edilen bilgiler dikkatli bir şekilde değerlendirilmiş ve NVIVO programı yardımı ile analiz edilmiştir. Elde edilen bulgular incelendikten sonra öneriler getirilmeye çalışılmıştır.

\section{Bulgular}

Elde edilen firma görüşmesi bulguları ve yapılan analizler sonucunda, en çok üzerinde durulan konuların başında gümrük işlemlerinin geldiği, genel işlemler ve prosedürlerin ikinci sırada yer aldığ görülmektedir. Bununla birlikte, belgeler ve elektronik ortam gibi önemli maddelerin de sıklıkla vurgulandığı açıkça ortaya çıkmaktadır. Zaman kayıpları, bilgilendirme ve yeterli bilgiye sahip olma, uyum, ithalat süreçleri ve ödemeler ise üzerinde durulan diğer konulardır.

Şekil 2'de firma yetkilileri ile yapılan görüşmelerden elde edilen verilerin analizi sonucu elde edilen kelime bulutu gösterilmektedir.

Şekil 2. Firma Yetkilisi Görüşmeleri Kelime Bulutu

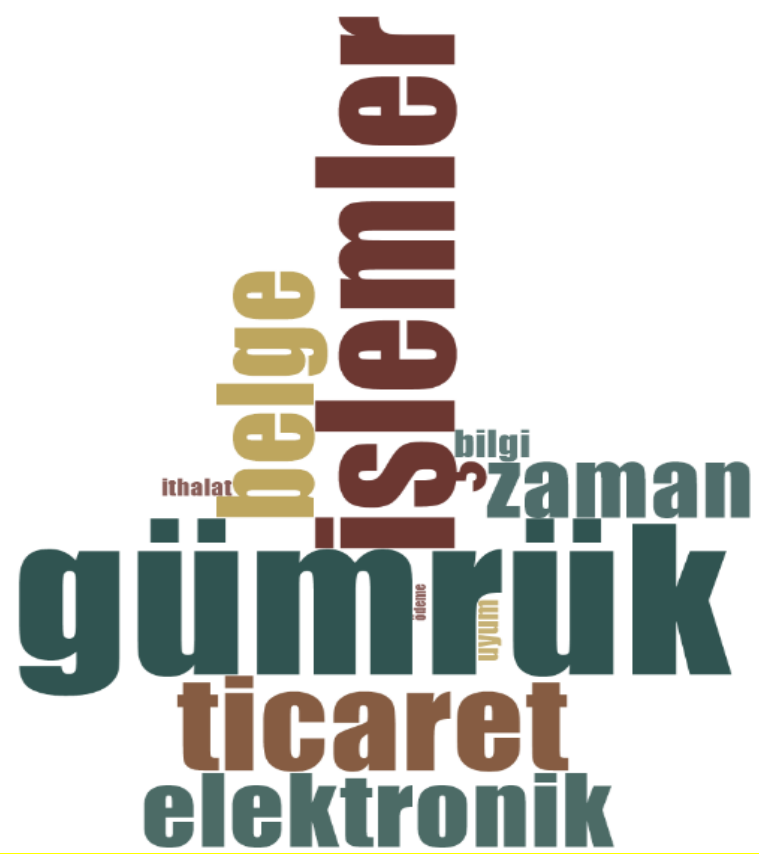

Kaynak: Yazar Tarafından Düzenlenmiştir.

Elde edilen veriler, detaylı bir şekilde analiz edilmiş, NVIVO programı kullanılarak en çok üzerinde durulan konular ve kelimeler elde edilmiştir. Oluşturulan kelime bulutu analizi, en çok üzerinde durulan konuların başında gümrük işlemlerinin geldiğini, genel işlemler ve prosedürlerin ikinci sırada yer aldığını göstermektedir. Belgelerin elektronik ortama geçişi, tek pencere sistemi, kağıtsız ticaret, ithalat ve ihracat sürecinde işlemlerin süreleri neticesinde ortaya çıkan zaman kayıpları, diğer öne çıkan diğer başlıklardır.

Şekil 2'de ise gümrük yetkilileri ile yapılan görüşmelerden elde edilen verilerin analizi sonucunda, görüşmelerde en çok üzerinde durulan kelimelerin oluşturduğu kelime bulutu verilmiştir. 
Şekil 3. Gümrük Yetkilisi Görüşmeleri Kelime Bulutu

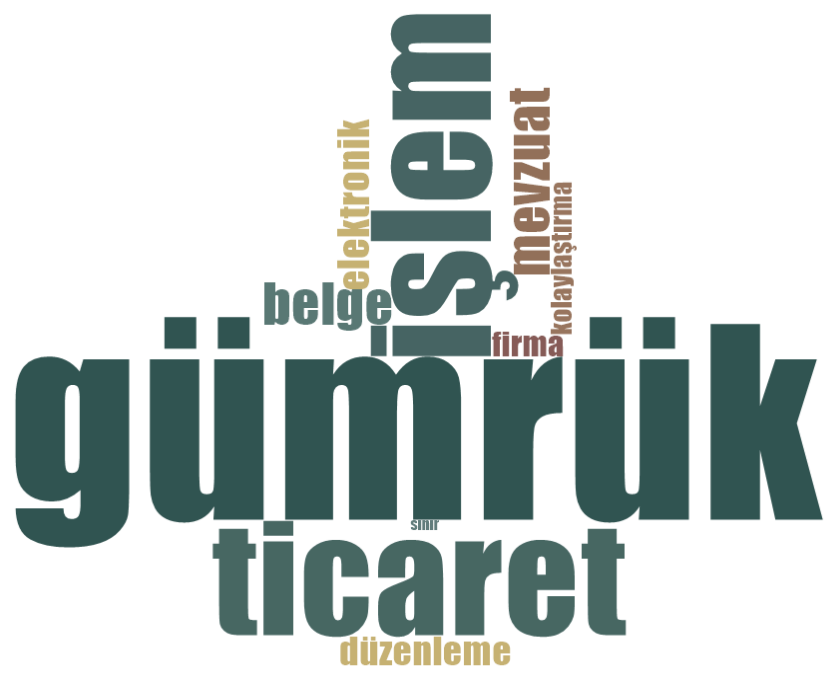

Kaynak: Yazar Tarafından Düzenlenmiştir.

Elde edilen veriler, NVIVO programı kullanılarak analiz edilmiş, analiz sonucunda görüşme yapılan yetkililerin en çok üzerinde durduğu konuların başında firma görüşmelerine paralel olarak gümrüklerin geldiği görülmüştür. Gümrüklerin ardından işlem ve prosedürler kelimeleri ön plana çıkmaktadır. Üzerinde durulan diğer konuların başında ise, belgeler, elektronik ortam, mevzuat ve düzenlemeler gelmektedir.

Görüşmelerden elde edilen veriler neticesinde elde edilen bulgular Tablo 1'de verilen ticaretin kolaylaştııılması göstergeleri esas alınarak 4 farklı başlıkta kategorize edilmiştir.

\section{Şeffaflı̆̆ın Să̆lanması}

Firmalar şeffaflığın sağlanması hususunda internet üzerinden ihtiyaçları olan mevzuat, tarife vb. bilgilere kolayca ulaşabildiklerini belirtmişlerdir. Ancak, yetkililer bahsi geçen bu yönetmelikler ve kısıtlamalar ile ilgili yeni bir düzenleme yapılması planlandı̆̆ında, bu yeni düzenleme ile ilgili bilgilere yürürlüğe girmeden önce ulaşamadıklarını belirtmiştir. Bu durum firmaların belirlenen düzenlemelere hazır olamamasına, maliyet ve zaman kaybına uğramasına yol açmaktadır. Ayrıca, TFA kapsamında önemli bir şeffaflık göstergesi olan, "Ticaret Erbabı ile İstişare" gereğince, ticaret yapan kişilerin yapılacak düzenlemeler ve uygulamalar ile ilgili yorum yapabilme ve sürece katkıda bulunabilme imkânı bulamadıkları belirlenmiştir. Şeffaflık kapsamında değerlendirilen BTB taleplerinin ise 15 günden 3 aya kadar değişkenlik gösteren sürelerde geri dönüş olması sebebiyle ticaret süreçlerinin yavaşladığı belirtilmiştir.

Gümrük Yetkilileri Şeffaflığın sağlanması hususunda firmaların cevaplarına paralel olarak internet üzerinden yönetmelikler, tarifeler ve bilgilere hızlı ve kolay bir şekilde ulaşabildiğini belirtmişlerdir. Yeni bir düzenleme planlandığında ise, gümrük başmüfettişlerinin bilgilendirildiğini, eğer firma görüşleri alınması öngörülürse ise sektör lideri çeşitli firmalara hakemlik ve yorum yapma fırsatı verildiği belirtilmiştir. Gümrük yetkilileri ile yapılan görüşmelerde BTBtaleplerinin cevaplanması süreci ile ilgili soru yöneltilmiş taleplerin 15 gün içerisinde yanıtlandığ 1 belirtilmiştir. 


\section{Ticari Maliyetlerin Azaltılması ve Prosedürlerin Kolaylaştırılması}

Firmalar'a ticaret sürecinde en çok zaman kaybına sebep olan işlem ve prosedürlerin neler olduğunu belirlemek üzere sorular yöneltilmiştir. Elde edilen bulgular, özellikle ithalat sürecindeki gümrük prosedürlerinin en çok zaman kaybına yol açtı̆̆ını göstermektedir. Ayrıca muayene ve kontrol işlemleri, lojistik ve taşımacılık süreci, belgelendirme, evrak onay süreçleri ve belgelerde ortaya çıan tekerrür ve fazlalık, mal bedeli tahsili veya ödemesi sorunları ve dövizin yurda getirilmesi işlemlerinin zaman aldığı ve ticari maliyetleri arttırdığ belirlenmiştir.

Prosedürlerin kolaylaştırılması kapsamında, en önemli maddelerden biri olarak, Tek Pencere Sistemi gösterilmektedir. Tek Pencere Sistemi, ticaret sürecinde kullanılan belgelerin ve yapılan işlemlerin elektronik bir portal üzerine taşınması, bilgi ve belge paylaşımının çevrimiçi olarak sağlanması ile ticaret sürecinin hızlandırılması anlamına gelmektedir. Firmalara Tek Pencere Sistemi'nin Türkiye'de ne denli uygulandı̆̆ını tespit etmek üzere sorular yöneltilmiş, Tek Pencere Sistemi'nin son yıllarda yaygınlaşmaya ve hali hazırda bazı uygunluk belgeleri, ithal izin belgeleri gibi dış ticaret belgelerinde kullanımının yaygınlaştığı görülmektedir.

Firmalar, ticaret sürecinde kullanılan belgelerin fazlalığına ve tekerrürüne değinmiş, bu durumun ticareti hızlandırmanın önünde engel teşkil ettiğini, zaman kaybına ve hatalara ve ekstra maliyetlere sebebiyet verdiğini belirtmişlerdir. Bazı otoritelerin ise elektronik ortamda kabulü mümkün olan belgeleri ıslak imzalı ve orijinal olarak talep ettiklerini belirtmişlerdir.

Uluslararası ticaret sürecindeki işlemler ve prosedürlerin kolaylaştırılması maksadı ile elektronik ortama dökülmesi TFA'nın ana maddelerinden bir tanesidir, ancak ticareti kolaylaştırma süreci küresel bir özveri gerektiren bir husus olarak karşımıza çıkmaktadır. Bu nedenle firmalarımıza sınır ötesi işlemlerinde karşılaştıkları, prosedürler, çalışma gün ve saatleri, uyum ve standardizasyon, belge ve veri paylaşımı gibi konularda sorular yöneltilmiştir. Elde edilen veriler, özellikle komşu ülkelerimiz ile yapılan ticarette büyük sorunlar yaşandığını ortaya koymuş, E-Belge kullanımının Batı Avrupa ülkeleri haricinde sorunlara sebebiyet verdiği görülmüştür. Ayrıca, ithalat ve ihracat sürecinde uygulanan prosedürlerin ve uygulamaların ülkeden ülkeye farklılıklar gösterdiği, standardizasyon sorunları ve bilgi eksikliklerinden ötürü, cezalar ve zaman kayıplarının ortaya çıtı̆̆ı, dolayısıyla ticari maliyetlerin bir hayli arttı̆̆ belirlenmiştir.

Gümrük Yetkilileri'nden alınan cevaplarda, ticareti kolaylaştırma kapsamında uygulanan prosedürlerin basitleştirilmesi, sonradan kontrol gibi uygulamaların yeterli seviyelerde olduğu ancak otomasyon sürecine odaklanılmasının işlemlerin daha hızlı şekilde yürütülmesine katkı sağlayacağı belirtilmektedir. Otomasyon ve sürekli gelişen teknolojilerin takibinin etkin bir şekilde yapıldığı takdirde, işlem sayılarında azalma ve zaruri olan işlemlerde hızlanma, ayrıca ticari maliyetlerin azalışının beklendiği vurgulanmıştır.

Gümrük yetkililerine yöneltilen, gümrüklemeyi geciktirebilecek potansiyel formaliteler olup olmadığı sorusuna ise gümrük mevzuatının açı ve net olduğu, ancak bazı durumlarda mevzuat dahilinde olmayan sorunlar ile karşılaşılabildiği ve personelin inisiyatif alması gerektiği belirtilmiştir. 
Gümrük yetkililerinden Tek Pencere Sistemi ve elektronik ortamda aktarılan bilgi ve belgeler hususunda edinilen bilgilere dayanarak, Tek Pencere Sistemi'nin büyük oranda başarılı bir şekilde uygulandığı görülmektedir. Birçok belge çevrimiçi olarak sunulmakta ve gümrük idarelerince bu belgelerin kabulü sorunsuzca gerçekleştirilmektedir. Gümrük işlemleri süresince oluşan maliyetler ve vergilerin ödenmesinde ise, GÜMKART online ödeme sistemi devreye sokulmuş ve çeşitli kolaylıklar sağlamıştır. Gümrük yetkililerince, çevrimiçi belge sisteminin ticareti hızlandırdığ 1 ve evraklarda yapılabilecek suiistimallerin önüne geçebileceği belirtilmiştir.

Gümrük yetkililerince üzerinde durulan bir diğer konu ise, Yetkilendirilmiş Yükümlü Statüsü (YYS)'dür. YYS, gümrük işlemlerinde kolaylık sağlayan uluslararası bir statüdür ve gümrük yükümlülüklerini yerine getirmekte sorun yaşayamayan, düzenli, büyük ve güvenilir firmalara tahsis edilmektedir. Bu statü sayesinde gümrük personeli üzerindeki yük azalmakta ve gümrük işlemlerindeki risk yönetiminin daha etkin bir şekilde yapılması amaçlanmaktadır. YYS ile firmaların diş ticaret işlemleri hızlanmakta, maliyetler düşürülmektedir.

\section{Sınır idareleri ve ticaret sürecinde rol alan tarafların iş birliği}

Firmalar, sınır kapılarındaki personel tarafından genel anlamda, gerekli özveriyi sağladığını, ancak gümrükler tarafından 7/24 çalışma prensibine geçilmesi gerektiğinin ticareti hızlandırma konusunda büyük faydalar sağlayacağını belirtmişlerdir. Firma yetkilileri tarafından belirtilen bir diğer önemli husus ise, sınır kapılarında standardizasyon ve uyumsuzlukların giderilmesidir. Sınır idarelerinin uyumsuzluklarından ötürü, kilometrelerce tır kuyruklarının oluştuğu, bu sebeple ticari maliyetlerin arttığı, teslimatların geciktiği ve ürünlerin bozulma tehlikesi ile karşı karşıya kalındığı belirtilmiştir.

Ülkelerin sınır kapılarında değişen prosedürler, yeni getirilen uygulamalar vb. değişimlerden haberdar olunmamasından ötürü, birçok ticaretin bozulduğu, tırların geri dönmesi gerektiği ve cezai işlemler uygulandığ 1 da verilen bilgiler arasındadır.

Firmalar tarafından üzerinde durulan bir diğer husus ise, ülkenin kurumları arasında bürokrasi sorunlarının yaşandığı, yetkin personel sayısının yeterli olmadığı ve işbirliği konusunda hala alınması gereken mesafelerin varlığıdır.

Gümrük yetkililerinden elde edilen sonuçlar analiz edildiğinde, gümrük personelinin eğitimi ve ticareti kolaylaştırma nezdinde yeni uygulamalara hızlı adaptasyonu konusunda sıkıntılar oluştuğu belirlenmiş ve bu yönde eğitim ve teknik desteklerin gümrüklerin kendi özelinde sağlandığı ortaya çıkarılmıştır. Ancak bu eğitim ve bilgilendirmelerin ülke genelinde T.C. Ticaret Bakanlığı tarafından verilmesinin önemi vurgulanmış ve gümrük işlemlerinin hızlandırılması açısından önemli bir husus olduğu belirtilmiştir.

Sınır idarelerimizin gün ve çalışma saatleri komşu ülkeler ile büyük oranda uyumlaştırılmış ve komşu gümrük idareleri ile karşılıklı veri paylaşımları için girişimlerde bulunulmuştur. Gümrük yetkilileri, firmalardan alınan görüşleri destekleyen, komşu ülkeler gümrük işlemleri ve prosedürlerinin uyumlu hale getirilmesinin önemini vurgulamışlardır.

\section{Kapasite ve Altyapının Geliştirilmesi}

Firmalar tarafından, kapasite ve altyapının geliştirilmesi üzerine yöneltilen sorulardan alınan cevaplar, ticareti kolaylaştırma kavramının altyapı ile desteklenmesi gerektiğini açıkça ortaya koymaktadır. Hızlı gelişen teknoloji ve küresel ağların genişlemesi ile günden güne artan ticaret hacmi, altyapı üzerinde büyük baskılar oluşturmaktadır. 
Elde edilen veriler neticesinde, en büyük altyapı sorunlarının başında limanların geldiği görülmektedir. Limanların yetersizliği, yoğunluğu ve limanlardaki bekleme sürelerinin fazlalığı, ayrıca limanlara ulaşımın zor olması ve yetersiz personel sorunları, altyapı sorunları olarak karşımıza çıkmaktadır. Limanlarda hasarlı, delik ve koku içeren konteynerler, sistemlerin yenilenmemesi ve fiziki anlamda yetersiz olunması hususları ise değinilen diğer maddelerdir.

Ayrıca gümrükleme süreçlerinin hızlı ve etkin işlememesi, kırmızı hat uygulamalarına fazla düşülmesi, lojistik firmalarının ve bankaların alanında uzman olmayan iş gücü ile çalışılması belirtilen diğer altyapı sorunları olarak karşımıza çıkmaktadır.

Gümrük yetkilileri ise gümrüklerde altyapıda, ticareti büyük ölçüde yavaşlatacak sorunlar olmadığını, teknolojik hizmetlerin, internet hizmetlerinin ve iç bağlantı yollarının sorunsuz olarak işlediğini belirtmektedir.

Ancak elektronik ortamda işlenen belgelerde sistem yoğunluğundan ötürü aksaklıkların yaşanabildiği, Tek Pencere Sistemi'nin mobil cihazlara entegre edilmesinin işlemleri hızlandıracağını belirtilmektedir. Gümrük yetkilileri tarafından üzerinde durulan bir diğer husus ise, Gümrük Tarife İstatistik Pozisyonu (GTİP) tespiti için gümrüklerin çalıştığ laboratuvarların yeterince hızlı hizmet vermemesi sebebiyle, taleplere hızlı bir şekilde cevap verilememesi olarak karşımıza çıkmaktadır.

\section{Tarafların Birbirlerinden Beklentileri}

Çalışma bulgularında, ticaret sürecinde rol alan gümrükler, gümrük yetkilileri ve firmalar ile yapılan görüşmeler sonucunda detaylı bilgiler elde edilmiş, ticaret sürecinin yavaşlamasına sebep olabilecek muhtemel sorunlar ile karşılaşılmıştır. Bu sorunların giderilmesi ve ticaret sürecinin sekteye uğramaması açısından tarafların birbirlerinden beklentilerinin ne olduğunun anlaşılması büyük önem taşımaktadır.

Elde edilen bulgular ışı̆̆ında, firmaların ticaret sürecindeki diğer taraflardan beklentileri aşağıdaki şekilde sıralanmıştır.

a. Gümrük işlemlerinin tamamen elektronik ortama dökülmesi, matbu belge kullanımının azaltılması ve nihai olarak kaldırılması, belge sayısının azaltılması ve yapılacak olan bu uygulamalar sayesinde ticaretin hılanması, ticaretin önündeki bürokrasi engellerinin azalması ve işlemlerin kolaylaşıp maliyetlerin düşmesi beklenmektedir.

b. Sınır komşusu ülkeler ile yapılan ticaretteki çalışma saatleri, günleri, prosedür uyumları ve ihracat yapılan ülkelerin prosedürleri, talep edilen belgeler, belgelerin detayları vb. konular ile ilgili net bilgilendirmenin sağlanması,

c. Gümrük personelinin istihdamında kalifiye personel alımına dikkat edilmesi ve istihdam edilen personelin iyi bir eğitime tabi tutulması,

d. Kırmızı hat uygulamalarının revize edilmesi,

e. Gümrüklerden talep edilen BTB gibi bilgilerin yasalar içerisinde belirtilen zaman çizelgesine sadık kalınarak net bir şekilde cevaplanması,

f. Planlanan yeni uygulama ve düzenlemelerde, sektörel bazda katkıda bulunabilme ve fikir beyan edebilme imkânının sunulması, 
g. YYS verilmesinin önündeki engellerin kaldırılması ve bu statüye sahip olabilme şartlarının revize edilmesi. Bu sayede sadece lokomotif şirketler değil, daha küçük çaplı güvenilir şirketlerin ticaret süreçlerinin hızlandırılabilmesi.

h. Tek pencere sisteminin tam anlamıyla faaliyete geçirilmesi ve ticaret sürecinde atılan her adımın taraflarca görülebilmesi, bilgilendirmenin arttırılması ve şeffaflığa daha da önem verilmesi,

i. Gümrüklerde personel inisiyatifine kalabilme durumunun ortadan kaldırılması ve yapılacak tüm işlemlerin şeffaf ve net bir şekilde belirlenmesidir.

j. Gümrükleme işlemlerinin eşya gümrüğe gelmeden önce başlatılabilmesi,

k. Ticaret odalarının ve devlet kurumlarının arasında iletişimin, eşgüdümün sağlanması,

1. Limanların ticaret sürecini yavaşlatması, altyapının yetersiz kalması nedeniyle ve yoğunluğun artmasından ötürü her geçen gün artan zaman kaybının önüne geçilebilmesi için limanlara yatırım yapılması ve personel sayısının arttırılması,

m. Limanlarda yaşanan bekleme ve işlemlerin gecikmesinin oluşturduğu maliyetlerin giderilmesi ve bu konuda yaptırımlar uygulanması,

n. Limanlara ulaşımlarda yaşanan iç yol problemlerinin giderilmesi,

o. Limanlarda kalifiye personel çalıştırılması,

p. Bankalarda kambiyo servislerinde uluslararası ticaret uzmanlığına sahip olmayan kişilerin istihdam edilmesinin önüne geçilmesi,

q. Taşımacılık sektöründe yer alan şirketlerin sorumlulukların arttırılması ve hasarlı, yetersiz konteynerlerin kullanilmaması,

r. Alıcı ve satıcı arasında yapılan sözleşmeye her iki tarafın da azami dikkat göstermesi ve bu sürece hâkim olması.

Gümrük yetkilileri ile yapılan görüşmeler sonucunda elde edilen bulgular ışığında, gümrük yetkililerinin işlemlerini hızlandırabilmesi için taraflardan beklentileri aşağıda belirtilmiştir.

a. Planlanan yeni uygulamalar ve yönetmeliklerde yapılacak olan değişimlerde yorum yapma fırsatının arttırılması, yapılacak olan düzenlemelerde belirli bir süre önceden net bir şekilde bilgilendirme yapılması. Ayrıca bu bilgilendirme sürecine diğer tarafların da dâhil edilmesi, bu sayede beklenen, tüm tarafların yeni uygulamalara önceden hazırlanabilmesi ve eşgüdümün sağlanması,

b. Dünyada yeni yürürlüğe giren teknoloji ve uygulamaların yakından takip edilip hızlı bir şekilde entegre edilmesi,

c. Gümrükleri ilgilendiren mevzuatların yeterince açık olmaması ve inisiyatif kullanmaya yer vermemesi nedeniyle bu konuda iyileştirmeler yapılması,

d. YYS'nün daha geniş yelpazeye ulaştırılması sonucunda gümrüklerdeki yoğunluğun azaltılıp selektif risk kontrolü yapmaya imkan sunulması,

e. Tek Pencere Sisteminin tam anlamıla hayata geçirilmesi ve elektronik belge kullanımının artırılmasına yönelik çalışmalar yapılması, mümkün olan her adımda elektronik ortama geçilmesi, 
f. Yeni yürürlüğe giren uygulamalar ile ilgili teknik destek ve eğitimlerin verilmesi,

g. Sınır kapılarında komşu ülkelerle çalışma, gün ve prosedürlerin uyumlaştırılmasına dair düzenlemelerin yapılması,

h. Kurumlar arası iletişimin artırılması, tüm uygulamaların aynı anda uygulamaya girmesi ve bilgi eksikliği yaşanmaması,

i. Firmalar ve diğer paydaşlar ile iletişimin artırılması, veri transferi için ulusal bir platform oluşturulması, Eğitim ve Yayım Bilgi Sistemi (EYBS) sistemindeki yoğunluk nedeniyle oluşan aksaklıkların giderilmesi ve mobil cihazların bu sistemi desteklemesi,

j. Firmaların gümrükleme sürecini, yetkin personel ile yürütmeleri, gümrükleme sürecinde açıç̧a belirtilen adımlara tam olarak hâkim olmaları ve talep edilen gereklilikleri doğru ve hızlı bir şekilde yerine getirmeleri. Bu sayede cezaların önüne geçilmesi, hızlı bir ticaret akışının sağlanması,

k. Ticaret sürecinde yer alan tüm paydaşların TFA gerekliliklerini benimseyerek kendi özelinde inisiyatif alması ve uygulaması,

1. Kötü niyetli firmalara caydırıcı cezalar verilmesini sağlayacak kanun ve düzenlemelerin yapılması,

m. Transit taşımacılıkta kullanılan Yeni Bilgisayar Transit Sistemi'nin genel olarak kabul edilmesi ve diğer ülkeler ile birlikte tam uyumun sağlanması,

n. Gümrüklerin çalıştığı laboratuvarların altyapılarının iyileştirilmesi.

\section{Sonuç ve Öneriler}

Uluslararası ticaret bir bütün olarak dikkate alındığında, bu tür faaliyetlerin ülkelerin ekonomik büyüme ve kalkınma performansına oldukça olumlu etkiler sağladığ görülmektedir. Türkiye ve OECD ülkelerinin gümrük sürecindeki maliyetleri ve harcanan zaman karşılaştırıldığında, ithalat ve ihracat işlemlerindeki maliyetlerin ve harcanan zamanın Türkiye'de OECD ortalamasının bir hayli üzerinde olduğu görülmektedir. Bu nedenle, maliyetleri arttıran ve ticaret sürecinde zaman kaybına sebebiyet veren işlem ve prosedürlerin kolaylaştırılması ve hızlandırılmasının dış ticaret hacmini artırarak ekonomilerin refah seviyesini yükseltmesi beklenmektedir. Bu çalışmada, ithalat ve ihracat yönetimi ve tedarik zinciri incelendikten sonra, TFA üzerinde durulmuş, TFA'nın performans göstergeleri ve Türkiye'nin bu göstergeler nezdinde durumu araştırılmıştır. Ayrıca ticaretin kolaylaştırılmasına yönelik uluslararası faaliyetler ve ülkelerin bu konudaki performansları açıklanmıştır. Çalışmada öncelikle ikincil veri kaynaklarından yararlanılmış ve literatür taraması yapılmıştır. Buradan elde edilen detaylı bilgilerle, ve TFA performans göstergelerindeki Türkiye'nin durumu göz önüne alınarak görüşme soruları hazırlanmıştır. Sonrasında birincil veri kaynağı olarak uzman görüşlerine başvurulmuş ve derinlemesine görüşmeler yapılmıştır. Görüşmelerde uluslararası ticaret zincirinin iki önemli tarafı olan firmalar ve gümrük idarelerine odaklanılmış, elde edilen bulgular ışı̆̆ında ticaretin hızlandırılması ve kolaylaştırılması için öneriler getirilmeye çalışılmıştır. Bu kapsamda, her iki tarafın da en çok üzerinde durduğu husus, gümrük işlemlerindeki kolaylaştırma uygulamalarına hız verilmesidir. Bu konuda en çok dile getirilen öneri, işlemlerin yüzde yüz elektronik ortama dökülmesi gerektiğidir. 
TFA, ticaret işlemlerinde elektronik ortama geçilmesi, e-belge kullanımının arttırılması, yapılan tüm işlem ve uygulamaların bu elektronik platform üzerinden taraflarla paylaşılmasını şart koşmaktadır. Bu bağlamda, teknolojik gelişmeleri ve bu alandaki uygulamaları yakından takip eden Türkiye'nin, ticaret sürecindeki işlemleri elektronik ortama aktarma faaliyetlerini artırması gerekmektedir. Türkiye'nin OECD performans göstergelerindeki yeri incelendiğinde açıkça görülmektedir ki, Ticareti Kolaylaştırma Kurulu ve T.C. Ticaret Bakanlığı elektronik ortama taşınma sürecinde daha ciddi adımlar atmalı ve ticarette rekabetçi avantaj elde etmek için hali hazırda olan çalışmalarını hızlandırmalıdır.

Firmalar, gümrükler ve kurumlar arasında iletişim kaynaklı zaman kayıpları olduğu görülmektedir. Gümrüklerden talep edilen bilgilerin gerekenden uzun zaman aldığı, ticaret sürecini yavaşlattığı düşünülmektedir. Bu hususta gümrüklerin laboratuvar altyapılarının iyileştirilmesi, bilgi sistem hizmetlerinin geliştirilmesi, kalifiye personel istihdam edilmesi ve personel eğitimine, teknik desteğe yüksek önem verilmesi önerilmektedir.

Gümrüklerde uygulanan kontrollerde, özellikle kırmızı hat uygulamalarında yoğunluk yaşandığ1, gümrük personelinin bu kontrolleri uygulamakta yetersiz kaldığ1 ve ciddi zaman kayıpları olduğu görülmektedir. Gümrük personeli üzerindeki yükün azaltılması, dolayısıyla daha selektif risk kontrolü uygulanması, ticaret operasyonunun ve gümrükleme sürecinin hızlandırılması maksadıyla, gümrüklere personel takviyesi yapılması, 7/24 çalışma prensibinin uygulanması, YYS'nin daha geniş bir kitleye yayılması, bu statüye sahip olma gerekliliklerinde kolaylaştırmaya gidilmesi ve tanıtım kampanyalarının yapılması önerilmektedir.

Altyapılar nezdinde ise, limanlarda yaşanan yetersizliklerden ötürü ticaret sürecinin yavaşladığı hatta durma noktasına geldiği, hasarlı konteynerler ve bozulabilir ürünlerin limanlardaki beklemelerden dolayı hasar gördüğü belirtilmiştir. Denizyolu ticaretinin dünya ticaretinin \%85 gibi bir bölümünü oluşturduğu ve Türkiye'nin üç tarafının denizlerle çevrili olduğu düşünüldüğünde, rekabetçi avantaj elde edebilmek için limanlarımız büyük önem arz etmektedir. Limanlarda altyapı iyileştirmeleri yapılmalı, ulaşım yolları kolaylaştırılmalı, personel takviyesi gerçekleştirilmelidir.

Türkiye'de hali hazırda ticaretin kolaylaştırılması için birçok çalışma ve iyileştirme yapılmaktadır. TFA'nın tarafı olunmasından bu yana, TFA performans göstergelerinde çeşitli iyileştirme ve geliştirmelerin yapıldığı ve göstergelerdeki puan ortalamalarının yükselme eğiliminde olduğu gözlenmektedir. Ancak, araştırmanın sonuçlarında ticareti kolaylaştırma uygulamaları ve iyileştirmelerinde ciddi sorunlarla karşılaşıldığı görülmektedir. Türkiye'de ticareti kolaylaştırma hususunda daha radikal değişiklikler yapılmalı, ticaret hacminin arttırılması ve ekonomik kalkınmaya fayda sağlanması için TFA ve göstergelerinin şart koştuğu geliştirme ve iyileştirmelere önem gösterilmelidir.

\section{Kaynakça}

Aynagöz, Ç. Ö. (2016). Wto-Ticareti Kolaylaştırma Anlaşması ve Türkiye İçin Değerlendirmeler. Afyon Kocatepe Üniversitesi Iktisadi ve Idari Bilimler Fakültesi Dergisi, 18(1), 3.

Bahçeci, S. (2018). Dış ticaretin kolaylaştırılmasında Türkiye'nin görünümü. İstanbul Ticaret Üniversitesi Girişimcilik Dergisi, 2(3), 75-88.

Deliçay, M. (2015). Dünyada ve Türkiye'de dış ticareti kolaylaştırmaya yönelik ulusal koordinasyon çalışmaları. Ankara: Kalkınma Bakanlığı İktisadi Sektörler ve Koordinasyon Genel Müdürlüğü. 
Duval, Y., Tengfei, W., \& Chortip, U. (2015). Trade Facilitation and Paperless Trade: State of Play and the Way Forward For Asia and Pasific. United Nations ESCAP Trade, Studies in Trade and Investment Working Paper(85).

Eymen, U. E. (2007). Tedarik Zinciri Yönetimi. Kaliteofisi Yayınları.

Grainger, A. (2014). Measuring-up customs: A trade compliance cost perspective. Nottingham: Nottingham University Business School.

Hillbery, R., \& Zhang, X. (2015). Policy and performance in customs: evaluating the trade facilitation agreement. Washington: World Bank Group.

Moïsé, E., Orliac, T., \& Minor, P. (2012). Trade facilitation indicators: the impact on trade costs. Paris: OECD.

OECD. (2015). Global trade costs could drop dramatically if countries implement WTO Trade Facilitation Agreement. https://www.oecd.org/: https://www.oecd.org/newsroom/global-trade-costs-coulddrop-dramatically-if-countries-implement-wto-trade-facilitation-agreement.htm adresinden alınd 1

Organisation for Economic Co-operation and Development. (2020). 11 16, 2020 tarihinde Trade Facilitation: http://www.oecd.org/trade/topics/trade-facilitation/ adresinden alınd 1

Organisation for Economic Co-operation and Development. (2020). 10 18, 2020 tarihinde Trade Facilitation Indicators: https://www.oecd-ilibrary.org/trade/trade-facilitation-and-the-globaleconomy_9789264277571-en adresinden alınd1

Orta Anadolu İhracatçı Birlikleri. (2020). 10 12, 2020 tarihinde Hakkımızda: http://www.oaib.org.tr/tr/default.html adresinden alındı

Özdemir, A. İ. (2004). Tedarik zinciri yönetiminin gelişimi, süreçleri ve yararları. Erciyes Üniversitesi İktisadi ve İdari Bilimler Fakültesi Dergisi(23), 89.

Sakyi, D., Villaverde, J., Maza, A., \& Bonuedi, I. (2017). The effects of trade and trade facilitation on economic growth in Africa. African Development Review, 29(2), 350-361.

The World Bank Group. (2020). 11 20, 2020 tarihinde Logistics Performance Index 2018: https://lpi.worldbank.org adresinden alınd 1

The World Bank Group. (2020). 11 20, 2020 tarihinde Doing Business Index 2020: https://www.doingbusiness.org/en/reports/global-reports/doing-business-2020 adresinden alınd 1

Ticaret Bakanlığı. (2020). 2 18, 2020 tarihinde T.C. Gümrük ve Ticaret Bakanlığı Ticaretin Kolaylaştıılması Türkiye Stratejisi ve Eylem Planı 2018-2022: http://www.canakkaleticaretborsasi.org.tr/haber-resim/buyuk/taslak-strateji-ve-eylem-planibelgesi-2b34.pdf adresinden alınd 1

UN/CEFACT. (2003). 09 15, 2020 tarihinde International Trade and Business Procedures Group Finance Domain: https://www.tbg5-finance.org/ToRTBG5rev3_Aug_03mod.pdf adresinden alındı

UN/CEFACT. (2012). 11 12, 2020 tarihinde The Buy-Ship-Pay Referance Models: http://tfig.unece.org/contents/buy-ship-pay-model.htm adresinden alınd1

UNDP, U. N. (2020). Sürdürülebilir Kalkınma Amaçları. 12 03, 2020 tarihinde www.tr.undp.org: https://www.tr.undp.org/content/turkey/tr/home/sustainable-development-goals.html adresinden alınd 1

Ünsal, S. S. (2007). Ticaretin Kolaylaştırılması Bağlamında Tek Pencere Uygulaması (Gümrük Müsteşarlığı Uzmanlık Tezi,). Ankara.

World Economic Forum-WEF. (2016). Global Enabling Trade Report. Cologny: World Economic Forum.

World Economic Forum-WEF. (2020). 11 20, 2020 tarihinde Global Competitiveness Report 2019: https://www.weforum.org/reports/the-global-competitveness-report-2019 adresinden alınd1 